\title{
How the Migrant Workers Affect Native Workers The Study of Basic Model
}

\author{
Yu-Cheng Lai \\ Department of Finance, Shih Chien University Kaohsiung Campus, No. 200 University Rd, Neimen, Kaohsiung 845, Taiwan \\ *Corresponding Author: br00846@yahoo.com
}

Copyright (C) 2013 Horizon Research Publishing All rights reserved.

\begin{abstract}
The increased labor supply of migrant workers can make up labor shortage of host countries. Based on basic theoretic study, this paper tries to build a model to investigate the effect of rising number of unskilled migrant workers on different skilled workers. It indicates that both wages and employment for unskilled and skilled native workers will increase because the labor demand of native workers, if the effect of higher production (scale effect) larger than the effect of substitution between migrant and native workers. On the other hand, the migrant workers will have different effect on skilled and unskilled native workers.
\end{abstract}

Keywords Foreign Workers, Native workers, Employment, Wages

\section{Introduction}

Nations has had to import workers to counter labor shortages brought on by economic growth. Four Asian tiger countries (Singapore, Hong Kong, Taiwan, South Korea) import a lot of foreign workers. At the same time, it faces a lot of criticism from native workers because the foreign workers may decline the wages and employment for native workers. Migrant employees relieve urgent demand of less-skilled native workers. However, the increased supply of migrant workers may affect the wages and employment of skilled/unskilled workers. The imported foreign workers will affect the relative labor supply in domestic market. Aydemir and Borjas (2007) claim that the immigrant will increase labor supply, but lead to the negative effect in the wage of competing native employees. Based on the study for the effect of migrant workers on wages and employment, this study will investigate whether the migrant workers will have different effect on skilled and unskilled workers?

We find both output and substitution effect based on basic theoretic analysis on foreign workers. And the labor market effects of foreign workers will be useful for the policymakers, especially those interested in understanding the impact of their policies on native labor market outcomes on employment and wages for skilled/unskilled workers, and finding out whether policies were effective at raising benefits in given outcomes.

The theoretic model is a basic model in this study, which the model may have a lot improvement in the future work. Such as, it may need to adopt the game theory to measure the effect between employers and employees. However, findings of the present study should not only provide the theoretical evidence for policymakers, but the results that have emerged from the country case study may be referred by other Asian countries who want to bring a change in wages and employment conditions for their labor by import foreign workers.

\section{Basic Theoretic Model}

Assuming that the labor supply of native workers remains constant, based on a previous study New and Zimmermann(1994), we developed a model to measure the effect of foreign workers on the employment and wages of native workers. The state of technology in Cobb-Douglas production function is represented by A. To avoid problems of firm size, fixed capital costs and number of firms, the convenient assumptions of constant returns to native labor $\left(L_{i}\right)$, foreign workers $\left(L_{f}\right)$ and capital $(\mathrm{K})$ were adopted. Where the $L_{i}$ includes different quality labor. $L_{1}$ indicates native workers and the number of foreign workers will have less effect on their jobs. We name these using low-impact (usually educated) native workers. On the other hand, $L_{2}$ indicates the high-impact (usually less educated) native workers that the foreign workers can take their jobs. $\mathrm{x}$ can measure the replacement ratio between high-impact native workers and foreign workers; and a higher $\mathrm{x}$ will indicate that more high-impact native workers are replaced with foreign workers. Using a Cobb-Douglas formulation production function in a firm is $F\left(K, L_{i}, L_{f}\right)$, and it is a homogenous production function. Prices of all manufactured goods will be equal to P. In Equation (1), Q can represent by production function for a firm by native and foreign workers, where $\alpha \gamma, \beta \gamma<1$ 


$$
Q=F\left(K, L_{1}, L_{2}, L_{f}\right)=A K^{\alpha \gamma} L_{1}^{\beta_{1} \gamma} L_{2}^{\beta_{2} \gamma} L_{f}^{\beta_{3} \gamma}
$$

All firms operate in a common set of factor markets for labor and capital whose prices ( $w_{i}, w_{f}$ and $\left.\mathrm{r}\right)$. The price of labor equals wage $\left(w_{i}\right)$. This study writes the cost expressions in (2), total cost is represented by $\mathrm{r}, w_{i}$, and $w_{f}$. In Equation (2), $\mathrm{C}$ indicates the cost of a firm hires both native and foreign workers.

$$
\begin{aligned}
& \quad C=r K+w_{1} L_{1}+w_{2} L_{2}+w_{f} L_{f} \\
& =r K+w_{1} L_{1}+(1+x) w_{2} L_{2}
\end{aligned}
$$

The firm hires both native and foreign workers for profit maximization that is expressed in Equation (3)

$$
\begin{aligned}
& \operatorname{Max} \pi=P F\left(K, L_{i}\right)-r K-w_{1} L_{1}-(1+x) w_{2} L_{2} \\
& =A K^{\alpha \gamma} L_{1}^{\beta_{1} \gamma}(1+x)^{\beta_{2} \gamma} L_{2}^{\beta_{2} \gamma}-r K-w_{1} L_{1}-(1+x) w_{2} L_{2}
\end{aligned}
$$

This study determines how the optimal choice functions respond to change in a parameter of replacement ratio between native and foreign workers (x). The optimal choices have to satisfy the first-order conditions. First-order conditions require $\pi_{k}=\pi_{L_{i}}=0$, which give, respectively

$$
\begin{aligned}
& \frac{\alpha \gamma \mathrm{P} Q}{K}=r \\
& \frac{\beta_{1} \gamma \mathrm{P} Q}{L_{1}}=w_{1} \\
& \frac{\beta_{2} \gamma \mathrm{P} Q}{L_{2}}=(1+x) w_{2}
\end{aligned}
$$

From these three first-order conditions (4), (5), and (6); the second order conditions established by (7) with respect to $\mathrm{x}$ (replacement ratio between native and foreign workers).

$$
\begin{aligned}
& \pi_{L_{1} L_{1}} \frac{\partial L_{1}}{\partial x}+\pi_{L_{1} L_{2}} \frac{\partial L_{2}}{\partial x}=0 \\
& \pi_{L_{2} L_{1}} \frac{\partial L_{1}}{\partial x}+\pi_{L_{2} L_{2}} \frac{\partial L_{2}}{\partial x}=w_{2}
\end{aligned}
$$

The second-order conditions are established in Equations (7). The determinant of the cross-partials of the objective function,

$$
\mathrm{D}=\left|\begin{array}{ll}
\pi_{L_{1} L_{1}} & \pi_{L_{1} L_{2}} \\
\pi_{L_{2} L_{1}} & \pi_{L_{2} L_{2}}
\end{array}\right|=\frac{\beta_{1} \gamma Q \times \beta_{2} \gamma Q\left(1-\beta_{1} \gamma-\beta_{2} \gamma\right) Q^{2}}{L_{1}^{2} L_{2}^{2}}>0
$$

It is important to determine the effects of a change in foreign workers on the labor market. Using Cramer's rule, we obtained

$$
\frac{\partial L_{1}}{\partial x}=\frac{-\left(1-\beta_{1} \gamma-\beta_{2} \gamma\right) \times w_{2} Q^{2}}{L_{1} L_{2}}<0
$$

$$
\frac{\partial L_{2}}{\partial x}=\frac{-\left(1-\beta_{1} \gamma\right) \times w_{2}}{\beta_{2} \gamma\left(1-\beta_{1} \gamma-\beta_{2} \gamma\right) Q^{2} L_{1}^{2}}<0
$$

The findings in Equations (9) and (10), the slope obtained from the employment of low-impact native workers $\left(L_{1}\right)$ and high-impact native workers $\left(L_{2}\right)$ differential with respect to the replacement ratio of foreign workers ( $\mathrm{x}$ ) will be negative. Therefore, the increase the replacement ratio of foreign workers $(x)$ is associated with a decrease in employment of low-impact native workers $\left(L_{1}\right)$ and high-impact native workers $\left(L_{2}\right)$.

Calculated from Equations (5) and (6), the high-impact and low-impact native workers' wage $\left(w_{1}, w_{2}\right)$ will be presented in Equations (11) and (12).

$$
\begin{gathered}
w_{1}=\frac{\beta_{1} K r}{\alpha L_{1}} \\
w_{2}=\frac{\beta_{2} K r}{\alpha(1+x) L_{2}}
\end{gathered}
$$

The migrant workers have both substitution and output effects on native workers. In regard to the substitution effect between skilled workers and migrant workers, based on Equation (9), the higher $\mathrm{x}$ will decline the $L_{1}\left(\frac{\partial L_{1}}{\partial x}<0\right)$, leading to higher $\log$ value of $L_{1}$ in right hand side of Equation (13). This implies that the higher $\mathrm{x}$ (replacement ratio between native and foreign workers) will increase the wage of educated native labor. As seen in equation (13), the substitution effect because migrant workers have a negative impact on employment of skilled workers, but increase wages.

$$
\begin{aligned}
& L o g w_{1}=\log \beta_{1}+\log K r-\log \alpha-\log L_{1} \\
& L o g L_{1}=\log \beta_{1}+\log K r-\log \alpha-\log w_{1}
\end{aligned}
$$

Based on Equations (10), assuming constant output, the substitution effect exists and the wages of less-skilled native workers decline as a result of $\mathrm{x}$ (replacement ratio between native and foreign workers) increase (as seen in equation 14). The higher wages for skilled workers will lead to a decline in employment. The substitution effect decreases the wages of less-skilled workers, but increases their employment.

$$
L o g w_{2}=\log \beta_{2}+\log K r-\log \alpha-\log (1+x)-\log L_{2}
$$

$\log L_{2}=\log \beta_{2}+\log K r-\log \alpha-\log (1+x)-\log w_{2}$

As for the output effect, the overall labor cost will decline in response to hiring more unskilled migrant workers. It adopts the $\log$ value in both sides in these two equations (5) and (6), and leading to two new equations (15) and (16). It assumes that two equations hold other factors constants. The profit-maximum firms will decline the price of products $(\mathrm{P})$, leading to a higher demand for them. Moreover, employers 
will invest more capital and hire more educated native workers and less-skilled foreign labor, leading to output (Q) increases. This is known as the output effect. As seen from Equations (15) and (16), the output increase raises both skilled and less-skilled worker wages and employment levels.

$$
\begin{gathered}
\log w_{1}=\log \beta_{1} \gamma+\log P Q-\log L_{1} \\
\log L_{1}=\log \beta_{1} \gamma+\log P Q-\log w_{1} \\
\log w_{2}=\log \beta_{2} \gamma+\log P Q-\log L_{2}-\log (1+x)(1 \\
\log L_{2}=\log \beta_{2} \gamma+\log P Q-\log w_{2}-\log (1+x)
\end{gathered}
$$

\section{Conclusion}

Regarding the output (scale) effect as a result of migrant workers, foreign workers can make up the labor shortage, leading to higher productivity as well as output. It will increase the labor demand of skilled labor (Jiang, 2006). On the other hand, the unskilled migrant workers will lead to substitution effect between native workers and unskilled migrant workers. Due to different output and substitution effects, there are two outcomes on employment and wages of skilled native workers in response to unskilled migrant workers.

First, if the output effect is larger than the substitution effect, labor demand increases. Hence, employment and wages for both skilled and less-skilled native-labor increase, New and Zimmerman (1994) indicated that the positive effect on employment and wage depends on whether the native worker job can benefit from migrant workers. However, immigration in Europe increased the wages of the less-skilled workers rather than skilled workers (Docquier et al., 2011).

Second, the situation will change if the output (scale) effect is smaller than substitution effect, then labor demand declines. Migrant workers decrease the wages of less-skilled workers, but increase their employment. On the other hand, it will decline the employment of educated workers, but increases wages. Based on data of Taiwan, Lai (2010) indicates, the low-skilled native workers will be replaced by migrant workers, and the wages of the native workers will decline. The reduction of the wages of native workers depends on how easily their jobs can be taken to migrant workers.

\section{Acknowledgments}

I would like to thank the Shih Chien University for providing us the grant for the research of this paper, and grant number is USC-100-05-05003.

\section{REFERENCES}

[1] Aydemir, A. and Borjas, G. J. 2007. "Cross-Country Variation in the Impact of International Migration: Canada, Mexico, and the United States," Journal of the European Economic Association ,5(4), 663-708

[2] Docquier, F., Özden, Ç. and Peri, G. 2011.”The Wage Effects of Immigration and Emigration," Policy Research Working Paper ,5556, World Bank, February 2011.

[3] Jiang, F. F. 2006. "Impact of foreign worker importation on the unemployment, occupational choice and wage rates of local workers," Taiwan economic forecast and policy ,37(1), 69-111.

[4] New, J. P. and Zimmermann, K. F. 1994. "Native wage impacts of foreign labor: a random effects panel analysis," Journal of Population Economics ,7(2), 177-192.

[5] Lai, Y. C. 2010. "The Effect of Migrant Workers on Labor in the Manufacturing Industry in Taiwan." Journal of International and Global Economic Studies, 3(2), 39-52. 